IJPSM

33,1

Received 29 July 2019

Revised 4 September 2019

Accepted 15 September 2019

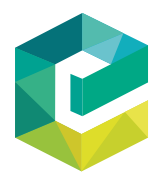

International Journal of Public Sector Management Vol. 33 No. 1,2020 pp. $22-44$ Emerald Publishing Limited 0951-3558 DOI 10.1108/IJPSM-07-2019-0195

\section{Searching for the renaissance bureaucrat} A longitudinal computer-assisted study of
personality traits in government vacancies

\author{
Peter M. Kruyen and Shelena Keulemans \\ Institute for Management Research, \\ Radboud University, Nijmegen, The Netherlands \\ Rick T. Borst \\ School of Governance, Utrecht University, Utrecht, The Netherlands, and \\ Jan-Kees Helderman \\ Institute for Management Research, \\ Radboud University, Nijmegen, The Netherlands
}

\begin{abstract}
Purpose - Since the early 1980s, western governments are assumed to have been either moving toward post-bureaucratic models or transforming into so-called neo-Weberian bureaucracies. As different public-sector (reform) models imply different ideal typical personality traits for civil servants, the purpose of this paper is to ask the question to what extent personality requirements that governments demand from their employees have evolved over time in line with these models.

Design/methodology/approach - The authors analyzed the use of big-five traits in a sample of 21,003 job advertisements for local government jobs published between 1980 and 2017, applying tools for computer-assisted text analysis.

Findings - Using multilevel regression analyses, the authors conclude that, over time, there is a significant increase in the use of personality descriptors related to all big-five factors.

Research limitations/implications - The authors postulate that governments nowadays are actively looking for the "renaissance bureaucrat" in line with the neo-Weberian bureaucracy paradigm. The authors end with a discussion of both positive and negative consequences of this development.

Originality/value - First, the authors explicitly link personality, public administration, and public management using the Abridged Big-Five-Dimensional Circumflex model of personality. Second, by linking observed trends in civil servant personality requirements to larger theories of public-sector reform models, the authors narrow the gap between public administration theories and practice. Third, the software tools that the authors use to digitalize and analyze a large number of documents (the job ads) are new to the discipline of public administration. The research can therefore serve as a guideline for scholars who want to use software tools to study large amounts of unstructured, qualitative data.
\end{abstract}

Keywords Personality traits, Job advertisements, Computer-assisted text analysis, Public-sector (reform) models Paper type Research paper

\section{Introduction}

An important conviction in the field of public administration is that government bureaucracies cannot be understood without insight into the personalities of the people working in them (e.g. Dahl, 1947; Merton, 1940; Wright, 2015). Personality refers to "a collection of stable individual characteristics and predispositions [that] is fundamental

(c) Peter M. Kruyen, Shelena Keulemans, Rick T. Borst and Jan-Kees Helderman. Published by Emerald Publishing Limited. This article is published under the Creative Commons Attribution (CC BY 4.0) licence. Anyone may reproduce, distribute, translate and create derivative works of this article (for both commercial and non-commercial purposes), subject to full attribution to the original publication and authors. The full terms of this licence may be seen at http://creativecommons.org/licences/by/4.0/ legalcode 
to understanding human attitudes and behaviours" and is commonly believed to shape how civil servants understand and perform their tasks (Cooper et al., 2013, p. 397). For decades, the alleged link between the organizational structure of bureaucracies, civil servants' personalities and performance (e.g. Baker et al., 1973; Dahl, 1947) has led scholars to inquire the extent to which bureaucracies select, shape and are appealing to certain personality types (e.g. Merton, 1940; also see Cooper et al., 2013; Dehart-Davis, 2007; Oberfield, 2014; Wilson, 1989).

The organizational structure of bureaucracies, however, is by no means static. Normative ideas about how bureaucracies ought to relate to their political and societal environment change over time (Osborne, 2010). These normative ideas often take shape in public-sector reforms (Hammerschid et al., 2016). Since the early 1980s, western governments are assumed to have been moving away from their Weberian rooted bureaucries toward post-bureaucratic models such as New Public Management (NPM) and New Public Governance (NPM), or as some observers have noted, have been transforming their Weberian bureaucracies into so-called neo-Weberian bureaucracies with a much more external societal orientation (e.g. Osborne, 2010; Pollitt and Bouckaert, 2004).

Since normative ideas about how governmental bureaucracies are, or should be, organized have developed considerably over time (e.g. Lynn, 2008; Olsen, 2005; Osborne, 2010; Pollitt and Bouckaert, 2004), one would expect congruent developments and changes in desirable personality traits of civil servants working in these bureaucracies as well. In this study, we ask to what extent and in what ways personality requirements that governments in practice demand from their employees evolved over time. To that end, we analyze the use of personality descriptors in a large sample of job advertisements for local government jobs published between 1980 and 2017 in the Netherlands. We apply the Abridged Big-Five-Dimensional Circumflex (AB5C) model of personality (Hofstee et al., 1992) and tools for computer-assisted text analysis.

We study job ads as they are a perfect outlet for employers to signal what they consider valued employee attributes (De Cooman and Pepermans, 2012). Job ads, generally, contain multiple sections including a description of the organization, task characteristics and candidate requirements. Building upon signaling theory (Rynes et al., 1991; Spence, 1973), research has shown that material in all sections is used (unconsciously) to obtain cues about the recruiting organization and preferred employee characteristics. Based on this image, potential applicants assess the degree of person-organization fit, job attraction and their chances to obtain the job (cf. Gaucher et al., 2011; Goldberg and Allen, 2008; Stevens and Szmerekovsky, 2010).

The current study aims to advance the field of public administration in three ways. First, although repeatedly called for (e.g. Merton, 1940; Wright, 2015), studies that explicitly link personality and public administration and public management are scarce (Cooper et al., 2013) and, moreover, fail to incorporate validated personality frameworks (Wright, 2015). We tackle this issue by systematically analyzing personality attributes in job ads using the AB5C model (Hofstee et al., 1992); a well-established taxonomy of personality traits developed in psychology. Second, by linking observed trends in civil servant personality requirements to larger theories of public-sector reform models, we aim to narrow the often hypothesized gap between public administration theories and practice (e.g. Kettl, 2002). Third, the current study advances the field in a methodological sense: the use of software tools with which we were able to digitalize and analyze a large number of documents (the job ads) is new to our discipline. Our research can therefore serve as a guideline for scholars who want to use software tools to study large amounts of unstructured, qualitative data.

This paper is structured as follows. First, we review three dominant public-sector (reform) models, focusing in particular on their often hidden or implicit assumptions about desirable personality traits. Second, we introduce the AB5C model of personality, which helps us to systematize personality traits and enables us to investigate personality characteristics empirically. Third, we explain how we extracted and analyzed desirable civil servant features from job vacancies using various computer-assisted text analysis tools and multilevel regression analyses.
Searching for the renaissance bureaucrat 
IJPSM

33,1

In the analyses that follow, we controlled our results for recruiting municipality, offered salary, type of function, and changes in economic conditions. Fourth, we reflect upon the implications of our research for understanding bureaucracies and governments in modern times. After discussing the limitations of this study, we end this paper with conclusions.

\section{$24 \quad$ Public-sector (reform) models}

The Weberian bureaucracy. As in many other countries, public administration in the Netherlands - the country in which this research was conducted - is rooted in Weberian bureaucracy (Andeweg and Irwin, 2002, p. 149). Weber built his concept of the bureaucracy on sharp distinctions between the formal and the informal, and the personal and the impersonal. The "formal impersonalism" of the bureaucracy, and its linkages to authority and legitimacy, led to a conception of the bureaucracy as a neutral institution or instrument, an "object" carefully to be separated from its "subjects" (Ansell, 2011, p. 65). As neutral executors, civil servants were assumed to be "cogs in the machine," required to perform their tasks as their superiors told them to (Torfing and Triantafillou, 2013).

The emphasis on neutrality and formalistic impersonality does not imply that civil servants' personality was not seen as a matter of interest. For even the portrayal of civil servants as neutral executors of public policy decisions, distinct personality traits are required such as being "methodical, prudent, disciplined," and displaying "an unusual degree of conformity with prescribed patterns of action" (Merton, 1940, p. 562). Governments were thought to attract employees with risk-averse and conformist personalities, drawn to the rules and predictability of bureaucratic organizations (Cooper et al., 2013; Dehart-Davis, 2007; Merton, 1940; Wilson, 1989). As Merton (1940, p. 565) stated: "The personality pattern of the bureaucrat is nucleated about this norm of impersonality." Reissman (1949, p. 310) translated the bureaucratic values further into the personality traits of a "good" civil servant, claiming that "the 'good' civil servant is one "who can get along with people,' who is 'honest' and 'loyal' to the department, and who is not so ambitious that he is constantly striving to 'get ahead'."

We emphasize that the degree to which the "ideal bureaucrat" in practice can be modeled after the principles of the Weberian impersonalized person has always been a matter of debate. Despite decades of theorizing about the links between Weberian bureaucracy and civil servants' personality (e.g. Allinson, 1984; Baker et al., 1973; Bozeman and Rainey, 1998; DeHart-Davis, 2007), it is important to note that strong empirical support for "the bureaucratic impersonality thesis" is lacking (DeHart-Davis, 2007; Wilson, 1989) and hence, still, a topic of research, including ours.

At a normative level, early works, such as those of Merton (1940) and Selznick (1957) in particular, questioned Weber's dichotomies between the personal/impersonal and the formal/ informal (Ansell, 2011). Merton (1940) discussed the dysfunctions of bureaucracy when the impersonal formalism escalates to the point where primary concern with conformity to the rules (call it radical "conscientiousness") in fact obstructs the achievement of the primary purposes of the organization (i.e. red tape). Selznick (1957) emphasized the continuing importance of the informal organization in large-scale organizations such as bureaucracies, in order to prevent the organization from becoming obsolete and disconnected from its environment, that is unresponsive to changing societal and political expectations and demands. Hence, as explained by Ansell (2011, p. 78), in contrast to Weber's model of neutral competence, Selznick stressed the need constantly to cultivate the organization's competence and character in order to make it a "responsive" organization.

Post-bureaucratic reform models. From the early 1980s onwards, we have witnessed a wide array of public-sector reforms that seem to imply a radical departure from the classical 
Weberian state and its bureaucracy (e.g. Osborne, 2010; Pollitt and Bouckaert, 2004). As explained by Olsen (2005, p. 6): "what started as an attack on 'bureaucracy' and its inefficient, costly, and rigid internal organization and operations has since then developed into a criticism of the role of public administration." The two most important exponents of these "post-bureaucratic" public-sector reform models are probably Anglo-Saxon NPM and its northwestern European challenger NPG (Klijn and Koppenjan, 2000; Osborne, 2010; Torfing and Triantafillou, 2013).

Complaints of rule-rigidity and red tape, combined with calls to adopt non-bureaucratic (market-like) principles in administration and lesser government interference, led to the introduction of NPM in many government bureaucracies of the 1980s and 1990s (Hood, 1991; Dunleavy et al., 2006; Olsen, 2005; Osborne and Gaebler, 1992; Torfing and Triantafillou, 2013). Hood (1991, pp. 4-5, italics in original) identified seven NPM-principles: "'hands-on professional management' in the public sector"; "explicit standards and measures of performance"; "greater emphasis on output controls"; a "shift to disaggregation of units in the public sector"; a "shift to greater competition in public sector"; "stress on private-sector styles of management practice"; and "stress on greater discipline and parsimony in resource use." Under NPM, the focus shifted from process accountability to accountability for outcomes (Bach and Bordogna, 2011, p. 2284; Behn, 2001) and from "management by command" to "management by contract" (Olsen, 2005, p. 6).

Even though the NPM has affected many government bureaucracies (Dunleavy et al., 2006), when, how and to what extent countries adopted its principles differed strongly by country and administrative tradition (Van de Walle et al., 2016). New Zealand and the UK are generally considered to be among the strongest implementors of NPM-principles and instruments (Bach and Bordogna, 2011; Kickert, 1997), while various continental European countries tended to neglect the NPM philosophy or only selectively implemented some of its instruments (Bach and Bordogna, 2011). In the Netherlands, NPM did shape public-sector reforms in the 1980s and 1990s, although its hardest - managerial - principles and instruments did fall out of fashion rather quickly (Hendriks and Tops, 2003).

In reaction to NPM, NPG-proponents postulate that one of the key tasks of modern - open - governments is to steer and manage in public-private networks (Kickert, 1997; Klijn and Koppenjan, 2000; Osborne, 2010; Thomas, 2013). Its core steering principle is governance by networks (Klijn and Koppenjan, 2000). Within NPG, civil servants are expected to stimulate the active participation of private stakeholders, who on their turn are envisaged to "chip in with their knowledge, ideas, and resources" (Torfing and Triantafillou, 2013, p. 12). Being able to navigate, adapt and aptly respond to constantly changing circumstances that include a variety of actors implies that civil servants should be flexible, be able to mediate, and have a cooperative and consensus seeking nature (e.g. Kickert, 1997; Olsen, 2005; Osborne, 2010). NPG is most strongly represented in northwestern European countries (Torfing and Triantafillou, 2013, p. 10), including the Netherlands (Kickert, 1997; Klijn, 2008).

On one level, NPM and NPG seem to rely on opposite prescriptions about how public administration should be organized in relation to society, and thus what is required from civil servants in terms of personality traits. Whereas NPM-advocates aim to transform the public sector and administration into a market-like organization, NPG-advocates opt for a more network-like organization. Yet, on a more fundamental level, they both seem to suggest a radical departure from the traditional personality characteristics of the Weberian bureaucrat along similar lines (Olsen, 2005). In particular, they expect civil servants to react promptly, responsively, and flexibly to changing circumstances - as there is no longer "one right way" to deliver public services (Dunn and Miller, 2007) - applying managerial styles and techniques, both within and outside their organization (Frederickson, 1996; Kickert, 1997; Klijn, 2008; Osborne, 2010).
Searching for the renaissance bureaucrat 
IJPSM

33,1

The neo-Weberian bureaucracy. In reaction to both NPM and NPG, several scholars have argued that governments were turning their eye back to the traditional Weberian bureaucracy (Van de Walle et al., 2016) in the late 1990s. However - in line with critical notes on the Weberian ideal by scholars like such as Merton (1940) and Selznick (1957) - they observed that the traditional Weberian bureaucracies were (or had to be) reconceptualized into much more personalized and politicized institutions (Lynn, 2008; Pollitt and Bouckaert, 2004).

As a descriptive concept of the distinctive (plural) identity of European continental public-sector reforms, the model of the neo-Weberian bureaucracy was meant to do justice to the distinct legal and cultural legacies and context of the (plural) European public administrations (Pollitt and Bouckaert, 2004; Pollitt, 2008). In line with traditional Weberian principles, neo-Weberians stress the constituting role of administrative law and of representative democracy in the citizen-state relationship. But in addition to this, they observed (and accordingly advocated) a shift from an internal orientation toward bureaucratic rules toward an external orientation toward meeting citizens' needs and wishes and attention to the creation of a professional culture of quality and service (Lynn, 2008, p. 27). "The 'bureaucrat' is not simply an expert in the law, but also a professional manager, oriented to the needs of his/her citizen/users" (Pollitt, 2008, p. 15). Yet, this external orientation of the neo-Weberian bureaucrat toward citizens should be firmly anchored within the distinctive status, culture, and terms and conditions of the public service, including equality before the law, legal security, and the availability of specialized legal scrutinity of state actions (Pollitt, 2008, p. 15).

\section{The AB5C model of personality}

To investigate the degree to which personality requirements that governments in practice demand from their employees have evolved over time in line with the forementioned publicsector (reform) models, we use the AB5C model. Developed by Hofstee et al. (1992), the AB5C model of personality relies on the lexical hypothesis which states that "the most important individual differences in human transactions will come to be encoded as single terms in some or all of world's languages" (Goldberg, 1993, p. 26). According to the AB5C model, personality characteristics - personality descriptors in terms of the AB5C model - can be classified using five broad, bipolar personality factors (denoted by Roman numbers below) labeled extraversion, agreeableness (or friendliness), conscientiousness, emotional stability, and openness to new experiences (or intellectual autonomy). Indeed, these factors are commonly known as "the big-five" personality dimensions.

To give a flavor of these factors, spontaneous, lively, and impulsive are related to the positive pole of the extraversion factor (I+), while quiet, apathetic, and timid are connected to its negative pole (also called introversion, I-). Flexible, loyal, and tolerant are linked to the positive pole of the agreeableness factor (II+), but bossy, harsh, and hot-tempered to its negative pole (II-). Diligent, thoughtful, and precise belong to the positive pole of the conscientiousness factor (III+), while reckless, disordered, and undisciplined are linked to its negative pole (III-). Self-confident, stable, and laconic are connected to the positive pole of the emotional stability factor (IV+), while fiery, depressive, and tearful are linked to its negative pole (also called neuroticisms, IV-). Open-minded, astute, and imaginative are linked to the positive pole of the openness to new experiences factor, $(\mathrm{V}+)$ but conservative, uncritical, and trivial to the negative pole of this factor $(\mathrm{V}-)$.

The AB5C model, however, posits that personality descriptors are not connected to one personality factor only, but "tend to represent blends of factors" (Hofstee et al., 1992, p. 146). That is, according to Hofstee et al. (1992), all personality descriptors are primary connected to one of these five factors, and secondary - i.e., less predominantly - connected to one of the other factors as well. This more fine-grained classification of a personality descriptor on the second factor - again using both poles of five personality factors - are called facets 
(denoted by Arabic numbers). In principle, the AB5C model consists of 100 factors $\times$ facet combinations, called clusters.

Table I lists keywords of the Dutch AB5C solution (adapted from De Raad and Doddema-Winsemius, 2015). Some clusters are theoretically empty - the grey cells in Table I - implying that we have no words that fit that particular cluster. For example, for the Dutch case, there are no words that describe people who are simultaneously extroverted and introverted. Moreover, about half of the filled 88 clusters contain solely negatively connoted personality descriptors in the Dutch language, including all clusters related to the negative poles of the five factors. We decided to exclude these clusters from the current study, as we expected these clusters never to be used in job ads. As a result, 39 clusters are theoretically relevant for the current project. These clusters consist of terms relating to one of the positive poles of one of the five factors (I+, II+, III+, IV+ and V+) in combination with either the positive or negative pole of one of the five facets $(1+, 2+, 3+, 4$ ,$+ 5+, 1-, 2-, 3-, 4-$ and 5-).

Two provisional hypotheses. We develop two provisional hypotheses about congruent developments and changes in desirable personality traits of civil servants, in terms of the $\mathrm{AB} 5 \mathrm{C}$ model of personality, in relation to the emerging models of bureaucracy and public-sector reforms. We call these hypotheses "provisional" in order to stress the exploratory character of our research.

To understand potential changes in desirable personality traits have over time, we need to consider the baseline situation, that is, the traditional Weberian Bureaucracy. In terms of the $\mathrm{AB} 5 \mathrm{C}$ model the desirable civil servant characteristics from the Weberian era suggest a high degree of conscientiousness (III+; e.g. "prudent," "methodical," and "honest"), emotional stability (IV+; e.g. "stable," "determined," and "imperturbable"), and little intellectual autonomy (i.e. openness to new experiences, V+; e.g. "obedient," and "conservative"). Also, using the vocabulary of the AB5C model, we would say that the "ideal" Weberian bureaucrat is required to be an "agreeable" person to a certain degree (II+; e.g. "loyal," and "compliant"), although bureaucrats were expected to display this trait in particular to their colleagues and superiors, but only indirectly to the general public (cf. Merton, 1940).

In contrast, the ideals of both NPM and NPG - our post-bureaucratic reform models - do not fit well with conscientiousness (III+) and emotional stability (IV+), while they are very much in line with the three other personality traits, being extraversion (I+; e.g. "spontaneous," "communicative," and "active"), agreeableness (II+; e.g. "flexible," "loyal," "responsive") and openness to new experiences (V+; e.g. "creative," "open-minded," and "reflective"). Hence, if it is true that both NPM and, later, NPG have gained dominance in the Netherlands since the 1980s at the cost of the Weberian model, we expect that changes occur in the personality characteristics asked for. This brings us our first provisional hypothesis:

H1. Since the 1980s, there has been an increase in the use of extraversion (I+), agreeableness (II+), and openness to new experiences $(\mathrm{V}+)$, and a decrease in the use of conscientiousness (III+), and emotional stability (IV+) in the job ads.

In contrast to what can be expected from the post-bureaucratic reform models, translating the neo-Weberian ideas into the terminology of the AB5C model, if it is true that the NeoWeberian state has gained dominance in the Netherlands, we expect that changes occur in the personality characteristics asked from the civil servant to make better connections to the outside world. This brings us to our second provisional hypothesis:

H2. Since the 1980s, conscientiousness (III+) as well as emotional stability (IV+) have not diminished in importance, but rather have been complemented over time by requiring more extraversion (I+), agreeableness (II+), and openness to new experiences $(\mathrm{V}+)$ in the job ads. 


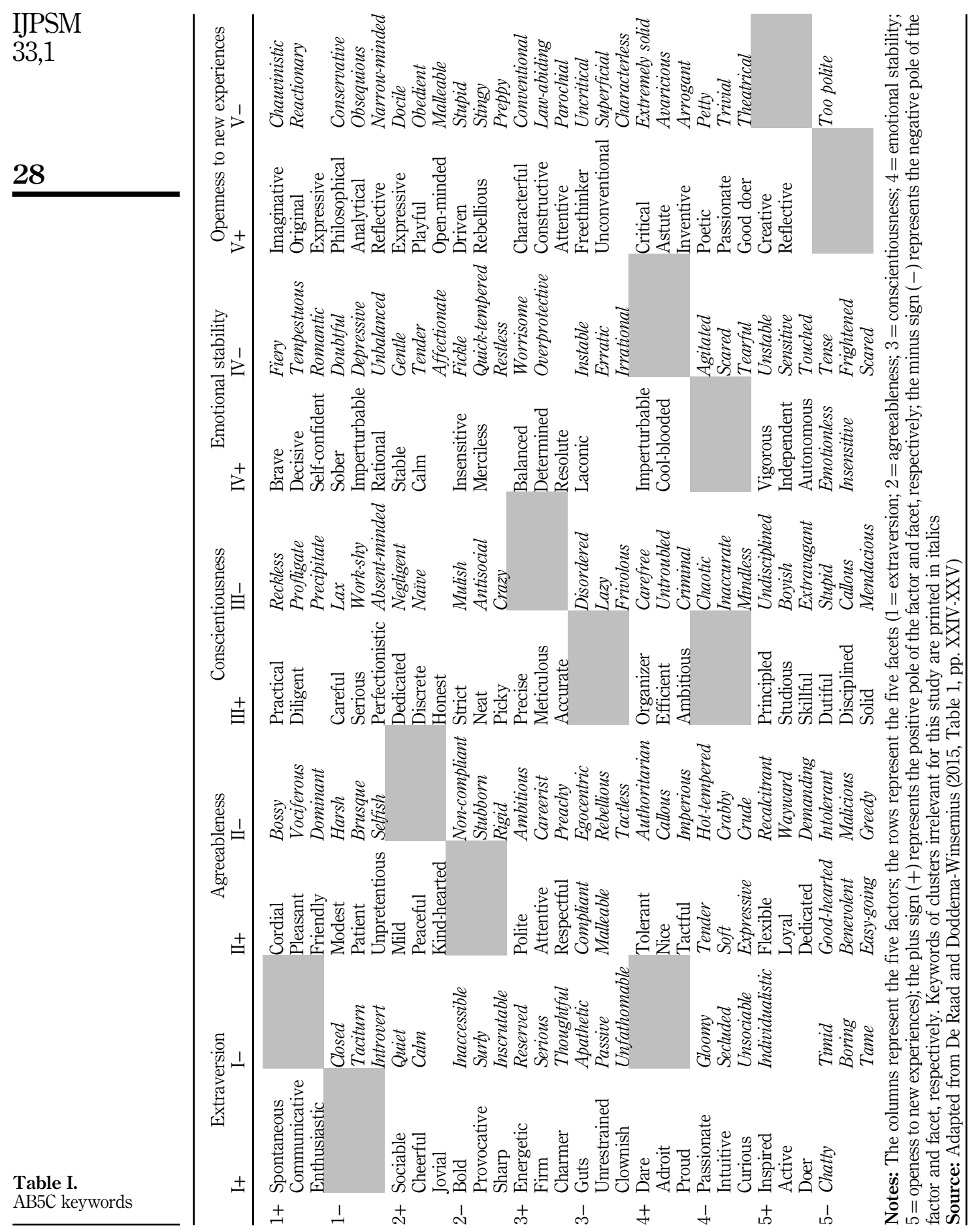


Method

Approach

To extract relevant data from the vacancies and perform the analyses, we programmed several scripts in $\mathrm{R}$ ( $\mathrm{R}$ core team, 2017).

\section{Sample}

The ads were published between 1980 and 2017 in Binnenlands Bestuur. Binnenlands Bestuur is a bi-weekly (before 2010 a weekly) Dutch magazine for civil servants. Currently, the magazine has about 46,000 subscribed readers, and its website (www. binnenlandsbestuur.nl) attracts 230,000 unique visitors every month. The amount charged by Binnenlands Bestuur to publish an ad in the magazine is determined by ad size, not by the number of words used. Concerning online ads, a fixed price is paid that neither does depend on the number of words used or the ad size. Prices have remained stable across time but have been corrected for inflation.

For the years 2008 and 2010-2017, we had access to a csv-file containing 14,804 ads that were published on the magazine's website (the electronic file that included the vacancies published in 2009 was corrupted). In order to process these vacancies correctly, we parsed them into R using the XML package (Temple Lang and the CRAN Team, 2017).

For 1980-2007 and 2009, we had to digitalize ads, as no electronic repository was available for these years. To digitalize job ads, we used Microsoft's Office Lens (2017) - a mobile smartphone app to photocopy documents - and Google's Vision (2017) - a software package developed by Google to extract text from images (a technique that is known as "optical character recognition") - that we accessed using Rooglevision (Cloudyr team, 2017).

Originally, we planned to digitalize all job ads for the years 1980-2007 and 2009. However, as it took considerable time to scan the job ads, we adapted our strategy during the data-collection process to keep the sampling procedure manageable. To start with, we collected all job openings printed in 1980. Given the amount of work involved, for 1981 and 1982, we digitalized only the first issue of each month. For the remaining years, to work more efficiently, we decided to scan ads that were published in the first issue of each quarter (i.e. the first issue of January, April, July and October issue). We sampled job ads from every quarter to control for a potential seasonal bias[1].

Some ads included multiple job openings for a single organization. As there can be carryover effects, we decided not to split these ads, but to consider them as a single ad. In contrast, we discarded job announcement we came across from 2002 forwards that included no other content but a job title and a link to a website. Neither did we include ads published by recruitment agencies that listed multiple job openings for different organizations. Lastly, we excluded ads posted by recruitment agencies in which the organization name was not revealed, making it impossible for us to control for municipality in the analysis.

To identify jobs for municipalities, we checked for occurrences of the term gemeente (i.e. "municipality") as well as stadsdeel and deelgemeente (i.e. terms used until 2004 for sub-municipal areas in Amsterdam and Rotterdam, respectively) in the job ads. Besides, we checked for the use of stad ("city") as we found out that several municipalities promoted themselves as city instead of municipality. To minimize the risk of errors we also checked for terms referring to other types of government organizations (e.g. "province," "ministry" and "semi-autonomous agency"). These ads were excluded from our analyses. We manually checked the ads for which we were unable to identify automatically the type of organization.

\section{Personality descriptors}

To identify personality descriptors in the job ads, we compiled a thesaurus of nouns and adjectives describing personality characteristics based on the Dutch compendium of the
Searching for the renaissance bureaucrat 
IJPSM

33,1

AB5C model (De Raad and Doddema-Winsemius, 2015). This compendium - compiled by Dutch personality researchers - lists nouns, adjectives, proverbs, and sayings describing personality characteristics per cluster (factor $\times$ facet combination). To construct the thesaurus, we first asked two professionals working in the field of job hunting to remove all multi-word expressions from the compendium by mutual agreement such as over het hart strijken ("to find it in your heart") and vat mensen bij de neus (literarily translated as "to grab people by their nose," i.e. "to trick people"). We asked both professionals to exclude those "terms" due to the technical complexities involved in their analysis and the risk of false positives. Meanwhile, we expected that these multi-word expressions were barely used in job ads.

To further minimize the risks of false positives, we also asked both professionals to remove ambiguous terms - that is, terms that are being used as to describe someone's personality, but which can also refer to a lot of other things, such as open ("open"), for example as in "an open person" but also as in "an open office." In a similar fashion, we instructed them to remove outdated terms. For example, for bewegelijk ("agile") the old-fashioned synonym kwikzilverachtig ("mercurial") was excluded. The initial list of nouns and adjectives was cross validated by the first and second author, who independently compared the compendium with the selection made by the practitioners. We decided to incorporate the few disputed terms in the thesaurus to minimize the risk of missing relevant terms. The preliminary thesaurus consisted of 341 terms, categorized per cluster, of which 24 terms appeared in multiple clusters.

The preliminary thesaurus contained still 16 terms that we regarded to be non-equivocally linked to personality in the Dutch language. To increase the validity of our research, we manually checked the context in which these words appeared in the ads using the keyword-in-context function in Quanteda (Benoit, 2017), using a random sample of 200 ads per terms. Of these terms, we excluded four terms (i.e. "social," "sweet," "generous" and "ruthless") which we judged to refer chiefly to other things than personality, based on the context in which these terms appeared. For example, the term "social" referred to social work, social policy and social law, but barely to a social person. Our final thesaurus contained 336 personality descriptors of which 23 terms appeared in multiple clusters. We note that the exclusion of the five ambiguous personality descriptors did not have any impact on our conclusions.

Lastly, we expanded the thesaurus with germane variations - including words containing spelling variations and errors - of the selected personality descriptors. For example, in the 1980s it was common in the Dutch language to use the letter " $k$ " instead of "c" (e.g. kreatief instead of creatief). Also, Google's Vision is not flawless, which is understandable given that optical character recognition is a complicated technical process. We compiled a list of all terms found in the sampled ads using Quanteda (Benoit, 2017), which we scanned for terms that slightly deviated - at most two characters - from the selected personality descriptors. To do so, we used the Levenshtein distance algorithm as implemented in stringdist (Van der Loo, 2014). Also, for personality descriptors with at least four characteristics, we scanned the term list using the personality descriptors minus their last two characters. For terms with fewer than four characters, we did not use this strategy, as it would result in too many false positives.

By means of this strategy, we identified 20,775 potential relevant variations of the terms in our thesaurus. These terms were manually checked by the first and second author for false positives. Terms were considered a legitimate variation if the likelihood of them referring to the applicant's personality or to the organization's collective personality was high. For example, creatieveling ("a creative person") is a legitimate variation of the personality descriptor creatief ("creative") as is oreatieve (extraction error of creatief), but recreatie ("recreation") is not. When in doubt, we compared dictionary definitions. 


\section{Other variables}

Year of publication. We coded the year in which an ad was published.

Municipality. To rule out the possibility that changes in the use of personality descriptors can be attributed to changes in a small number of municipalities, we included the municipal names in our analysis. As the result of numerous reorganizations, the number of Dutch municipalities decreased from 811 in 1980 to 388 in 2017. As "new" municipalities often (try to) start with a new identity, we considered old and new municipalities as separate entities. We extracted the municipality names from the ads using an iterative algorithm. We searched for the use of a municipality name in the vicinity of the term that signaled the type of organization using a list of Dutch municipalities (Statistics Netherlands, 2017a). If no municipality name was found, we considered information in the e-mail addresses and websites mentioned when available. During the process, we found out there were (minor) errors in the digitalization process causing the matching algorithm to fail, or we came across a "new" municipality name that was not on the original list of municipalities. We used this information to update our list of municipality names and re-run the matching algorithm several times.

Salary. A preliminary analysis showed that the ads in our sample were aimed at attracting employees with at least a vocational degree, but with different levels of experience for a wide array of different functions in different policy domains. Unfortunately, it turned out to be very difficult to make meaningful comparisons across specific functions and educational requirements, as job titles, descriptions of policy domains, and names of educational requirements changed considerably over time. As a proxy for required job qualifications, we used the offered monthly gross salary if reported. We extracted the digits after the Gulden sign (i.e. f) - the Dutch currency prior to the euro - or euro sign (i.e. $€$ ) in ads published till 2001 and from 2002 onwards, respectively. In case multiple salaries were detected (e.g. minimum and maximum offered salary), the mean salary was computed. Salaries above $f 10,000.00$ and $€ 10,000.00$ were assumed to be annual salaries and, hence, we divided the salary by 12 to obtain the estimated monthly remuneration. For the analyses, we standardized salary data to facilitate comparison across time as explained in the next section.

Type of function. As another proxy for required job qualifications, we checked for the appearance of terms that referred to a management function, including hoofd ("head"), leidinggevende ("manager") and teamleider ("team manager"). We coded an ad as an opening for a management function if at least one of such terms occurred in an ad's first sentences (specifically, in the first 30 percent of the terms), because a person with a management function was often mentioned as contact person at the bottom of an ad as well. If no such terms were found, we coded the job ad as an opening for a non-management function.

Change in gross domestic product (GDP). The use of personality descriptors may or may not dependent on changes in economic conditions. We used change in GDP as a proxy for change in economic conditions (Statistics Netherlands, 2017b).

\section{Analyses}

To investigate changes in the use of personality descriptors over time controlling for municipality, change in GDP, salary and type of function, we conducted multilevel regression analyses. In these analyses, job ads (first level) were nested in municipalities (second level). Type of function and salary were level-1 predictors. Change in GDP was a level-2 predictor. As dependent variable, we first considered the use of personality terms at the cluster level, next we considered the use of personality terms at the factor level.

Given the unequal distribution in the use of personality terms in the job ads, we binary coded the data. That is, for the analyses at the cluster level, ads that did not contain any references to a particular cluster were coded " 0 " for that cluster; ads that contained at least one references to a particular cluster were coded "1" for that cluster. Likewise, for the
Searching for the renaissance bureaucrat 
IJPSM

33,1

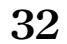

analyses at the factor level, ads that did not contain any references to a particular factor were coded " 0 " for that factor; ads that contained at least one references to a particular factor were coded " 1 " for that factor. The binary variables containing information regarding the absence (i.e. " 0 ") or presence (i.e. " 1 ") of references to a cluster or factor were used as the dependent variables. We applied multilevel generalized-linear-modeling using the lme4 package (Bates et al., 2015).

Extracted salaries were standardized by year to avoid problems caused by salary changes over time. Also, year of publication and change in GDP were standardized to obtain identified models and to compare estimated effect sizes. Parameters were estimated using the REML criterion. We estimated random intercepts and random slopes for year of publication for the included municipalities. For the empty model, we computed the interclass-correlation coefficient (ICC) using $\pi^{2} / 3$ as approximation for the residual variance as we are dealing with logistic regression (Moineddin et al., 2007).

Unfortunately, 31 percent of the ads did not include salary information. As the $\operatorname{lm} 4$ package cannot handle variables with many missing values well, we decided to impute missing values for the salary variable. To do so, we applied the MICE algorithm (Van Buuren and Groothuis-Oudshoorn, 2011) using predictive mean matching as the estimation method, 50 iterations and all other variables as predictors at the cluster level and the factor level, respectively. To investigate the stability of the findings, we imputed 20 data sets. The regression results were stable across the imputed data sets. Hence, we decided to report the mean results of the imputed data sets. Small discrepancies between the results at the cluster level and results at the factor level are due to the fact that we imputed missing data at both levels of analyses separately.

\section{Results}

\section{Descriptive results}

Our sample contains 21,003 job ads for local civil servants published by 875 municipalities [2] (mean number of ads per municipality $=24 ; \mathrm{SD}=33.66$; minimum $=1$, maximum $=488$ ) between 1980 and 2017 in Binnenlands Bestuur. On average, we sampled 552.70 ads per year $(\mathrm{SD}=231.08 ; \min =273 ; \max =1,317)$. The average ad contained 401.90 terms $(\mathrm{min}=24$; $\max =2,413 ; \mathrm{SD}=202.78$ ). Of the ads in our sample, 4,891 ads were identified as a job opening for a management function $(23.3 \%)$. The average extracted unstandardized mean salary rose from $€ 1,613.98$ ( $f 3,556.73)$ in 1980 to $€ 4,377.54$ in 2017. GDP changed, on average, by $2.06 \%$ ( $\mathrm{SD}=1.84 \%$; $\min =-3.80 \%$; $\max 5.10 \%)$. Vacancy length increased considerably over time from 242 terms on average in the $1980 \mathrm{~s}(\mathrm{SD}=85.13$, $\min =39$, $\max =1,015)$ to $567.30(\mathrm{SD}=246.64 ; \min =26 ; \max =2,413)$ in the 2010s[3]. The online Appendix provides for all descriptors the number of valid variations found in the data and the number of ads that contained at least one variation of that descriptor[4].

The gross data show a steady increase in the use of descriptors over time. Whereas in the 1980 s about 50.3 percent of the ads contained descriptors, this percentage rose to $81.7 \%$ in the $1990 \mathrm{~s}, 94.2$ percent in the 2000 s and 94.8 percent in the 2010 s. In a similar vein, we observe an increase in the diversity of descriptors used. On average, an ad in the 1980s included 0.90 descriptors $(\mathrm{sd}=1.15 ; \min =0 ; \max =9$ ), 2.6 descriptors in the $1990 \mathrm{~s}$ $(\mathrm{sd}=2.35 ; \min =0 ; \max =18), 4.34$ in the 2000s $(\mathrm{sd}=2.86 ; \min =0 ; \max =19)$, and $7.0 \mathrm{in}$ the 2010s $(\mathrm{sd}=4.28 ; \min =0 ; \max =39)$.

Figure 1 depicts the gross changes in the use of personality descriptors for the positive poles of the five factors. Interestingly, the use of personality descriptors for all five factors rose steadily over the years. Despite the limited use of personality descriptors in the early 1980 s, in line with our expectations, job ads contained relatively many references to the consciousness (III+) factor and emotional stability (IV+) factor in that period. 


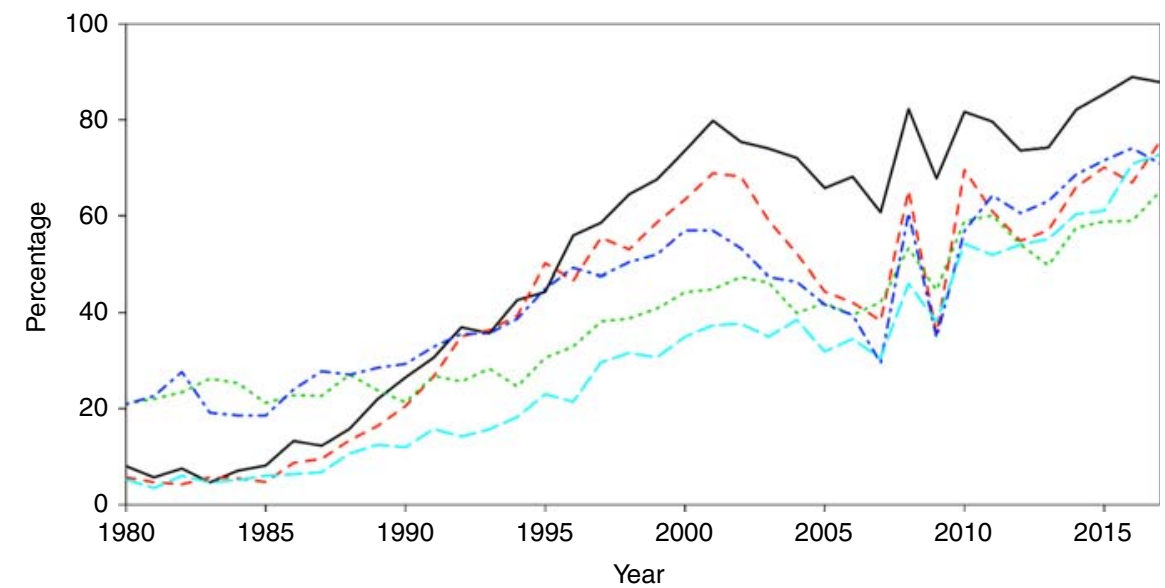

Notes: For all factors, the results of the positive poles and negative poles of the facets are combined. Black $=$ Extraversion $(\mathrm{I}+)$; Red $=$ Agreeableness $(\mathrm{II}+)$; Dark blue $=$ Conscientiousness $(\mathrm{III}+)$; Green $=$ Emotional stability $(\mathrm{IV}+) ;$ Light blue $=$ Openness to new experiences $(\mathrm{V}+)$
Searching for the renaissance bureaucrat

Figure 1.

Changes over time in the use of personality descriptors for the positive poles of the five factors

Hence, based on the trends shown in Figure 1, both hypotheses seem to be partially supported. On the one hand, the data show - in line with both provisional hypotheses - an increased attention over time for personality descriptors linked to extraversion (I+), agreeableness (II+) and openness to new experiences (V+). On the other hand, the data show - in contrast to both hypotheses - over time that attention for descriptors linked to conscientiousness (III+) and emotional stability (IV+) have increased as well.

\section{Multilevel regression models}

To rule out a potential confounding influence of differences across municipalities, differences in salary or type of function and the impact of changing economic conditions on our results, we turn to the results of the multilevel regression models. Tables II and III show the results for the multilevel regression models at both the cluster and factor level, for the positive and negative poles of the facets, respectively.

To illustrate how both tables can be read, consider the top pane of Table II. This pane shows the statistics for the clusters containing terms related to the positive pole of the extraversion factor $(\mathrm{I}+)$ and the five positive poles of the five facets $(1+, 2+, 3+, 4+$ and $5+)$, and moreover shows - in italics - the results for the positive poles of the facets combined. The first row displays the results for the cluster containing terms related to the positive pole of the extraversion factor (I+) and the positive pole of the extraversion facet (1+). We see that about 35.9 percent of the job ads contained at least one personality descriptor related to this cluster (Column 2). Moreover, some municipalities use personality descriptors related to this cluster more often than other municipalities given the ICC-value of 0.15 (Column 3). Next, we find the statistics for the intercept plus all variables. In addition to the estimated regression weights, standard errors, and $z$-values, a variance component is reported for both the intercept and year. We added a random effect for both variables, because - as suggested by the moderate ICC-values - some differences exist among municipalities in their use of personality descriptors.

In line with Figure 1, Tables II and III in general show a significant increase in the use of personality descriptors for all five factors over time (Columns $8-11$ ) controlling for salary (Columns 12-14), type of function (Columns 15-17) and change in GDP (Columns 18-20). 


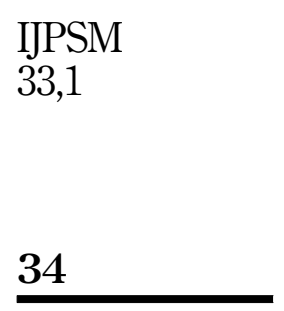

Table II.

Changes over time in the use of personality descriptors for the positive poles of the factors, positive poles of the facets

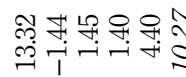

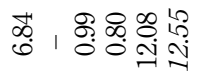

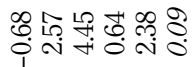

늄뉴, 용

ஜํํㅇํㅇㅇํㅇ ㄴ.

녕융영 1 융 응

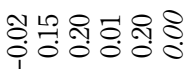

웅둥슝

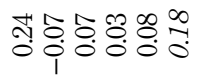

壱,

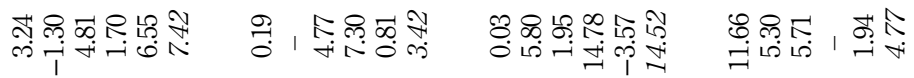

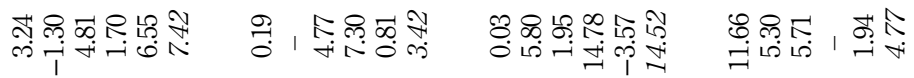

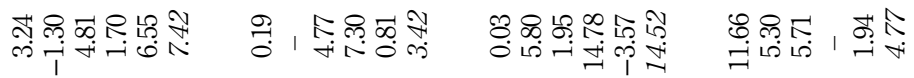

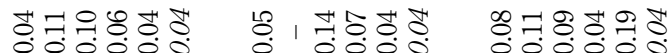

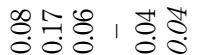

둥,

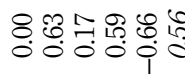

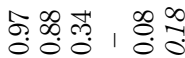

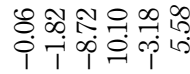

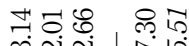

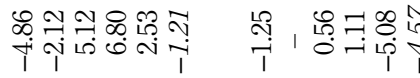

1

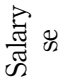

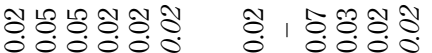

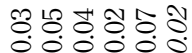

অ용요

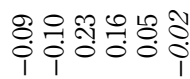

ڤ,

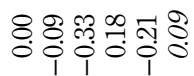

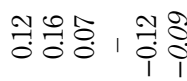

ซิำกำำ

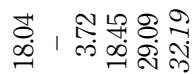

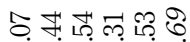

늑요용, 충 궁

药琼

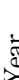

छ

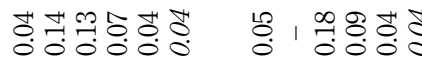

ஸ़่

సิ 1

웅융융 융 융

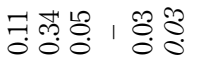

กำ 귱ำฺ

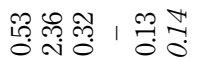

ஸேஷ

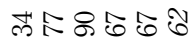

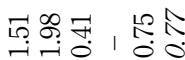

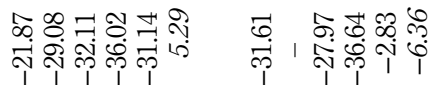

구 ํํ용ำ

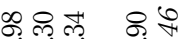

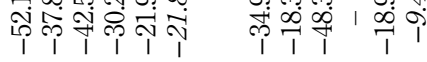

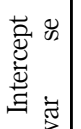

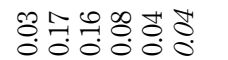

유.

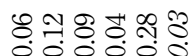

壱芯是, $18 \%$

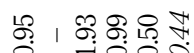

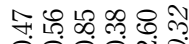

ণิ

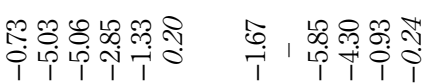

\section{苞}

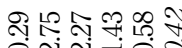

૫)

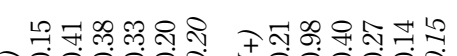

ฐँ๖

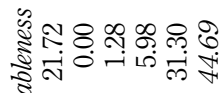

เุ

के

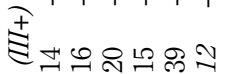

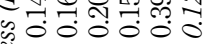

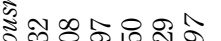

है เง

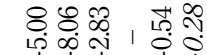
× 1 । 1

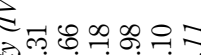

령

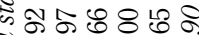

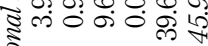

证匍古南古古

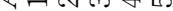




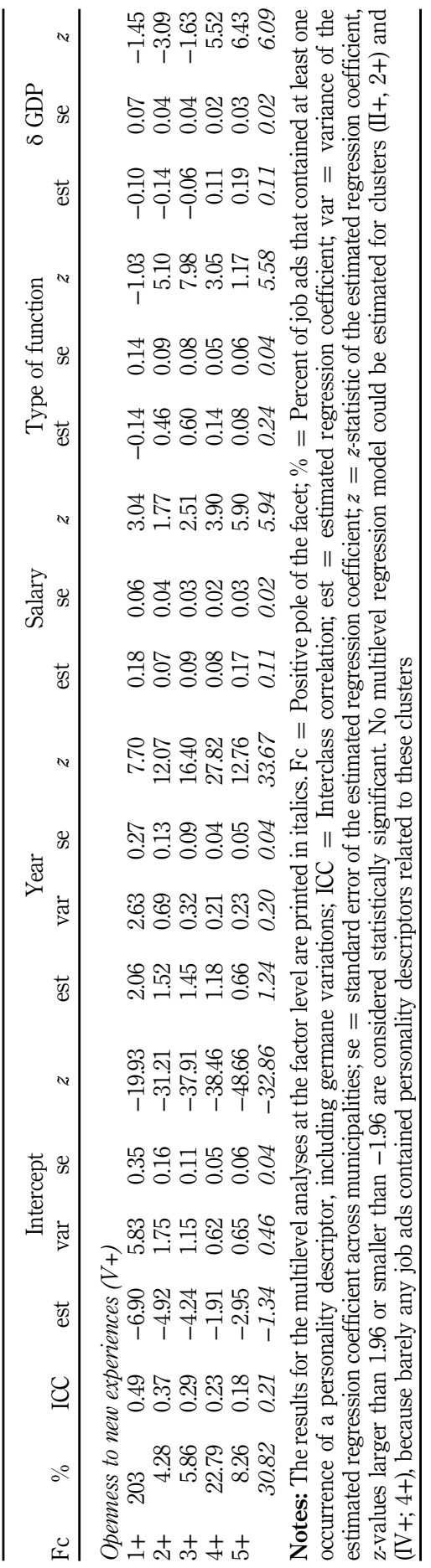

Searching for the renaissance bureaucrat 


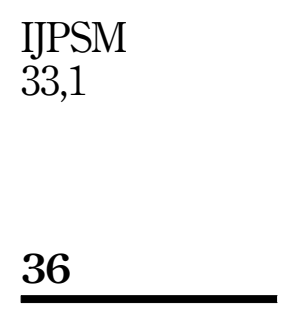

Table III.

Changes over time in the use of personality descriptors for the positive poles of the factors, negative poles of the facets

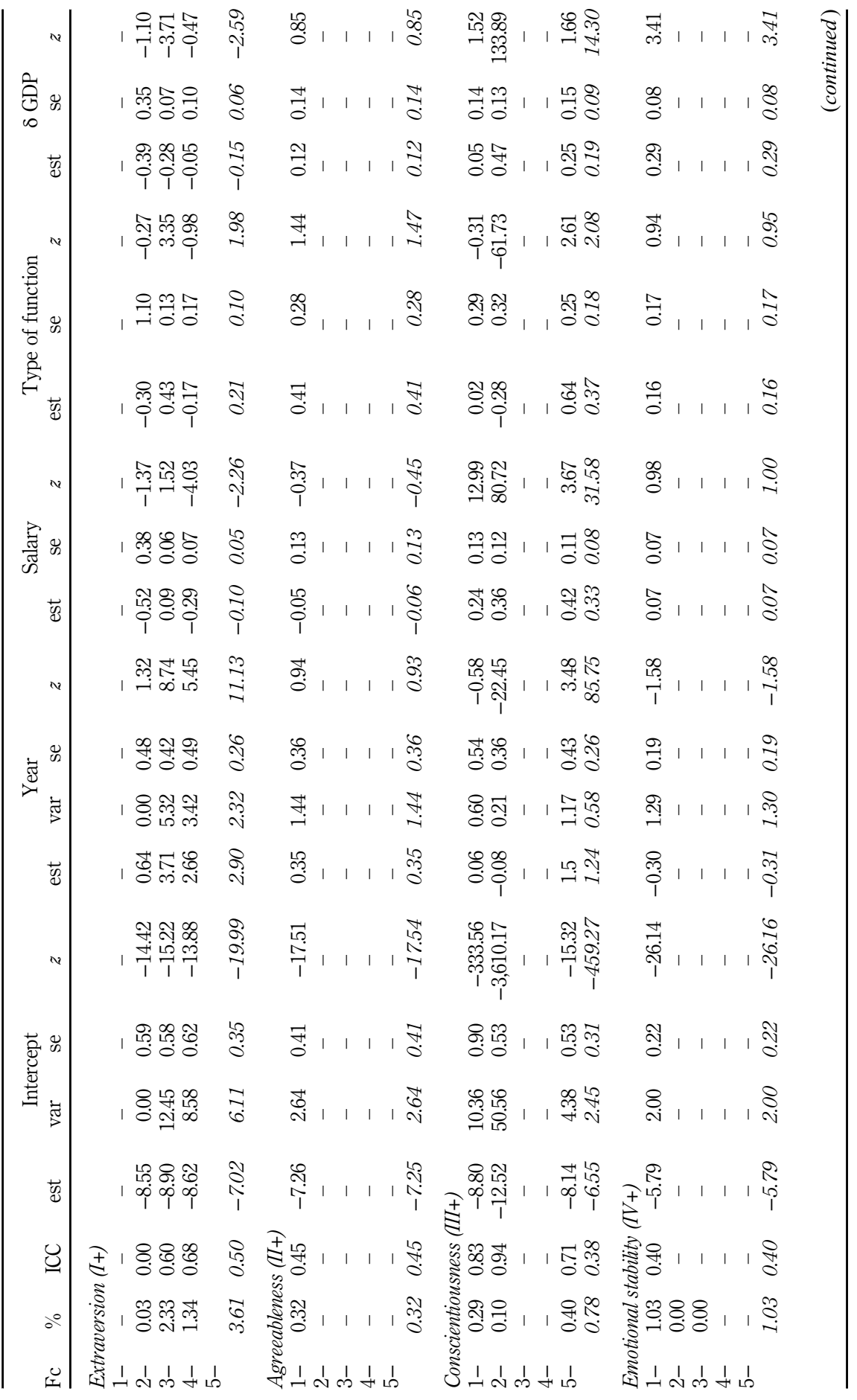




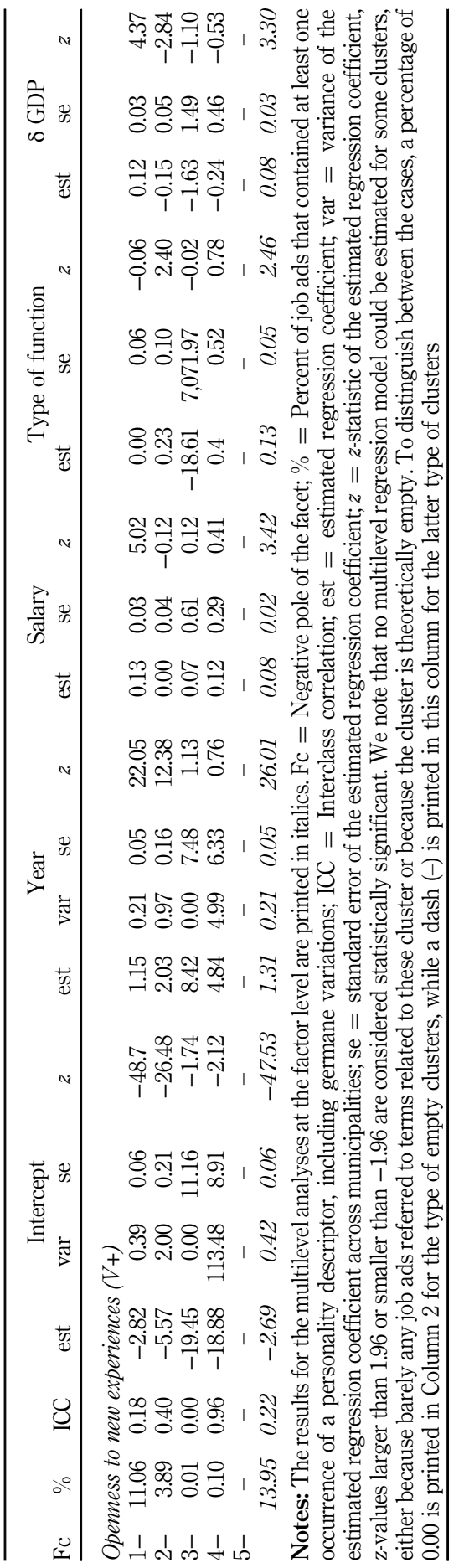

Searching for the renaissance bureaucrat 
IJPSM

33,1

Hence, both provisional hypotheses can only be partially accepted. On the one hand, the data show - in line with both hypotheses - an increase in attention for personality descriptors linked to extraversion (I+), agreeableness (II+) and openness to new experiences (V+). On the other hand, the data show - in contrast to both hypotheses - attention for descriptors linked to conscientiousness (III+) and emotional stability (IV+) have increased as well. We note that the results for the clusters with the positive poles of the facets in Table II are more pronounced than the results for the clusters with the negative poles of the facets in Table III, which can be attributed to the small number of personality descriptors that are related to these negative poled clusters compared to the positive poled clusters rather than to a lack of use in the job ads (i.e. 278 descriptors vs 71 descriptors).

As a byproduct of our analyses, the data show that - in general - there is more attention to personality for managerial positions than for non-managerial positions and when economic conditions improve. In contrast, the relationship between personality descriptors and salary is inconsistent. For some clusters and factors, the relationship is positive, while for other clusters and factors, the relationship is negative.

\section{Discussion}

In this study, we aimed to document to what extent and in what ways personality requirements that governments demand from their employees in practice have evolved over time in line in with public-sector (reform) models. We did so by investigating if and how the use of big-five personality characteristics of the desired civil servant changed in job ads for local civil servants changed in the last four decades. In line with both provisional hypotheses, there was indeed a significant increase in the use of personality descriptors related to extraversion (I+), agreeableness (II+), and openness to new experiences $(\mathrm{V}+)$ controlling for recruiting municipality, offered salary, type of function, and changes in economic conditions. However, in contrast to both hypotheses, we also found an increase in the use of descriptors related to consciousness (III+) and emotional stability (IV+) over time.

How to interpret these findings? Our results do not necessarily so imply that the Weberian model had no practical implications for Dutch civil servants in the early 1980s. We speculate that the lack of attention for personality attributes in most job ads in that period should not be interpreted as a lack of attention for personality, but rather as a sign that desirable personality traits for Dutch civil servants were largely taken for granted at that time. Specifically, we postulate that traits linked to consciousness (III+) and emotional stability (IV+), but not extraversion (I+), agreeableness (II+), and openness to new experiences $(\mathrm{V}+)$ were presupposed for (newly hired) civil servants in line with Weberian bureaucracy.

The steady increase of personality descriptors related to extraversion (I+), agreeableness (II+), and openness to new experiences (V+) from the mid-1980s onwards ties in with public-sector developments linked to post-bureaucratic reform models and the neo-Weberian bureaucracy. Moreover, the increased attention for personality descriptors related to consciousness (III+) and emotional stability (IV+) has to be understood in our view as an attempt to balance the need for personality traits related to the other three big-five factors as can be derived from the work of proponents of the neo-Weberian bureaucracy (Lynn, 2008; Pollitt and Bouckaert, 2004).

Hence, based on our empirical findings, we do not argue that post-bureaucratic reform models like NPM and NPG have not been relevant for successive public-sector reforms in the Netherlands, but speculate that their non-bureaucratic organizational principles have been capsulated within the emerging neo-Weberian model. In other words, from the mid-1980s onwards we postulate that the bureaucracy has not become an obsolescent organization in Dutch public administration, but instead seems to transform into a much more personalized and open institution in which the classical internal orientation toward 
bureaucratic rules and administrative law is supplemented or complemented with a more external orientation as was already called for by authors like Merton (1940) and Selznick (1957) and later by neo-Weberian scholars (Lynn, 2008; Pollitt and Bouckaert, 2004).

We acknowledge that other factors may explain the observed trends as well. We discuss three alternative explanations. First, several studies have discussed how trends related to NPM made government bureaucracies more aware of the importance of employee competencies for organizational performance (Hood and Lodge, 2004; Kruyen and Van Genugten, 2020). Hence, it can be speculated that the influence of NPM on personality traits asked for is more indirect than we argued in this study. For example, it can be that creativity has always been importance for civil servants, but was only included in the job ads when civil servants working at personnel departments (and later human resource departments) decided it was important to explicitly address the need for creativity in the job ads. To explore this alternative explanation, further archival research is needed.

Second, from an open system perspective on organizations, one could argue that the external orientation of the bureaucracy is essential for its functioning and for the preservation of its distinct structure and status (Scott, 2003, p. 89). Government bureaucracies have to adapt to the same social forces as other organizations, but since we have not compared job ads of public and private organizations for this study, we cannot distinguish between those that are deemed to be typical for the public sector and those that are of a more general nature. This assertion harbors an important limitation of the current study. Further research into the similarities and differences between job ads in different sectors would allow us to unravel the degree to which developments in the use of personality descriptors can indeed be linked to public-sector reform models or need to be attributed to general organizational and societal trends, such as the introduction of open offices (cf. Zalesny and Farace, 1987), millennials entering the workforce (cf. Hershatter and Epstein, 2010) and a general increase in attention for employees' personality attributes in the workplace, dubbed the "psychologization of work" (cf. Godard, 2014; Schaufeli, 2013).

Third, we assumed that the job ads in our data set reflect organizational reality. However, it is an empirical question for future research to investigate to what degree those who write job ads, and thus decide whether or not to include certain personality descriptors, include personality descriptors on purpose or not, and even if they do so, are (sub) consciously aware of their links to various public-sector models and other, more general organizational and societal trends. Instead, it can be that - in line with institutional isomorphism (DiMaggio and Powell, 1983) - those who write job ads include personality descriptors because they see others are using these terms as well. Nevertheless, as we observed considerable variation in terms used across municipalities and individual job ads, there is no indication of a simple "copy-paste" process. Alternatively, the observed increase of personality factors in job ads could also be understood as a sign of the increase of the use of "marketing" strategies in recruitment advertising. Such marketing strategies not necessarily so serve to attract the most suitable candidates, but are aimed to strengthen the image of the recruiting organization (Belt and Paolillo, 1982; Ryan et al., 2000), which - as side note - can be related to NPM trends too.

Besides having these various explanations, we want to draw attention to two specific research limitations that also provide avenues for future research. First, due to the limited availability of job ads for positions in other levels of government, we only used Dutch municipalities in our study. The choice for the municipal level can be justified by the central role of local governments in the Netherlands for policy development and implementation (Hendriks and Tops, 2003), but we welcome studies in which developments in governmental agencies at different levels and, also, in different countries are compared. For example, we know that between-country differences exist in the adaptation of various public-sector reform models (Bach and Bordogna, 2011; Van de Walle et al., 2016). In the Netherlands and

Searching for the renaissance bureaucrat 
IJPSM

33,1

other continental European countries, the NPG became quite popular (e.g. Kickert, 1997; Torfing and Triantafillou, 2013), while other countries still adhere to the NPM-principles (Van de Walle et al., 2016). These country-specificities raise the question of whether these differences translate in different trends in the use of personality descriptors too.

Second, we applied computer-assisted tools to analyze the job ads in our sample. Even though we assume that the relative advantage of human coders on the number of coding errors made is offset by the large volume of ads the computer-assisted tools allowed us to process, we are open to a replication study by human coders in which they, for example, use a random sample of our coding results as point of departure. In a similar vein, although we checked the context in which various ambiguous personality descriptors occurred, we were unable to systematically investigate the context in which the personality descriptors appeared. Also, we were unable to investigate potential changes in connotations of terms, although we do not have any evidence that since the early 1980s the meaning of the investigated personality descriptors have changed. Nevertheless, human coders, especially if they use more qualitative-oriented methods, are better equipped to investigate the context and meaning of texts, and hence, their coding efforts may enrich the findings presented in this study.

Taken these limitations into consideration, we speculate that the increased use of personality descriptors related to all big-five factors can be interpreted as a growing concern for, or need of, various personality characteristics to enhance the performance of government organizations. As has been argued by Olsen, contemporary practitioners in public administration do many different things, including: law-application, expert-advice, service provision, support building, and resource mobilization (Olsen, 2005). They are both rule-driven bureaucrats and calculating (NPM) or networking (NPG) managers. Our results shed an interesting light on what is expected from such a neo-Weberian bureaucrat. That is, the "ideal" typical neo-Weberian bureaucrat essentially is a "Renaissance bureaucrat"; the cultured man or woman of the late modern era, from whom we desire to perform brilliantly in many different ways and circumstances, like Leonardo da Vinci did in his time.

The increased attention for civil servants' personality in job ads has both potential benefits and risks that we think deserve further investigation. First, although studies did address the link between personality and performance (e.g. Baker et al., 1973), there is still much debate about the precise effects of personality on performance (e.g. Griffin and Hesketh, 2004). Research addressing this debate is the more important given the general assumption that more of a personality trait always benefits performance (cf. the discussion about the "maximization fallacy" in Anderson et al., 2014), even though several authors have shown that too much of a certain personality trait, including creativity, ambition and flexibility, can be risky for government organizations as well (Cohen, 1970; Reissman, 1949). To illustrate, Cohen (1970) found that - as the opposite of bureaucratic rule-rigidity - flexibility could become a "demonic of bureaucracy" too. Like rule-rigidity, flexibility could result in goal displacement and become dysfunctional to bureaucracy; leading bureaucrats away from attaining organizational objectives, harming clients in the process.

This raises the question to what extent it is possible to meet all the requirements of the Renaissance bureaucrat in practice? In this respect, our study provides support to the thesis that our workplaces have been "psychologized" in the last few decades (Godard, 2014; Schaufeli, 2013) which can have serious consequences for employees' health and well-being (cf. debates on the effects of emotional labor, Holman et al., 2008). For example, Baker et al. (1973) argued that if the personality demands of bureaucratic organizations are not compatible with the personality traits of their civil servants, civil servants experience psychological strain and difficulties in fulfilling their organizational roles and task requirements. Research is welcome to investigate how bureaucrats cope with this psychologization process in practice. 


\section{Acknowledgments}

The authors express gratitude to Binnenlands Bestuur's editorial office - in particular, Jose Salhi - Vossen and Marcel van der Meer - for giving the authors access to their archives and their research assistance. The authors thank Esther de Putter and Tessa Maas for their help in the renaissance bureaucrat constructing the thesaurus of personality descriptors. The authors also thank the reviewers and the editor for their remarks and suggestions. Lastly, the authors acknowledge Simon Maasland for building the mobile plateau the authors used to digitalize the printed job ads.

\section{Notes}

1. We note that additional statistical analyses provided no evidence for a potential seasonal bias in personality characteristics asked for. Technical details of these analyses can be obtained from the first author.

2. Because many of the "new" municipalities started with a new municipality name and we considered old and new municipalities as separate entities, the number of municipalities in our sample is larger than the number of municipalities in the Netherlands in 1980. To check for possible distortion effects imposed by municipalities that either ceased to exist or were newly constructed, we reran the regression models using only ads issued by the 359 municipalities that existed during the investigated period (1980-2017). These additional analyses show no evidence of differences between the remaining municipalities and the municipalities that "died." Technical details of these analyses can be inquired from the first author.

3. We note that post hoc analyses showed that our conclusions were not altered after including ad length as independent variable in our models. Technical details of these analyses can be obtained from the first author.

4. The Appendix can be retrieved from https://osf.io/trk8g/?view_only=4378cec04e4546fdb0 f67d4d73a3d12d

\section{References}

Allinson, C.W. (1984), Bureaucratic Personality and Organization Structure, Gower, Aldershot.

Anderson, N., Potočnik, K. and Zhou, J. (2014), "Innovation and creativity in organizations: a state-ofthe-science review, prospective commentary, and guiding framework", Journal of Management, Vol. 40 No. 5, pp. 1297-1333.

Andeweg, R.B. and Irwin, G.A. (2002), Governance and Politics of the Netherlands, Palgrave, Houndmills.

Ansell, C.K. (2011), Pragmatist Democracy: Evolutionary Learning as Public Philosophy, Oxford University Press, Oxford.

Bach, S. and Bordogna, L. (2011), "Varieties of new public management or alternative models? The reform of public service employment relations in industrialized democracies", The International Journal of Human Resource Management, Vol. 22 No. 11, pp. 2281-2294.

Baker, S.H., Etzioni, A., Hanson, R.A. and Sontag, M. (1973), "Tolerance for bureaucratic structure: theory and measurement", Human Relations, Vol. 2 No. 6, pp. 775-786.

Bates, D., Mächler, M., Bolker, B.M. and Walker, S.C. (2015), "Fitting linear mixed-effects models using Lme4", Journal of Statistical Software, Vol. 67 No. 1, pp. 1-48.

Behn, R.D. (2001), Rethinking Democratic Accountability, Brookings Institution Press, Washington, DC.

Belt, J.A. and Paolillo, J.G.P. (1982), "The influence of corporate image and specificity of candidate qualifications on response to recruitment advertisement", Journal of Management, Vol. 8 No. 1, pp. 105-112.

Benoit, K. (2017), “Quanteda: quantitative analysis of textual data”, R package version: 0.9.9-65, available at: http://quanteda.io

Bozeman, B. and Rainey, H.G. (1998), "Organizational rules and the 'bureaucratic personality', American Journal of Political Science, Vol. 42 No. 1, pp. 163-189. 
IJPSM

33,1

Dahl, R.A. (1947), "The science of public administration: three problems", Public Administration Review, Vol. 7 No. 1, pp. 1-11.

De Cooman, R. and Pepermans, R. (2012), "Portraying fitting values in job advertisements", Personnel Review, Vol. 41 No. 2, pp. 216-232.

De Raad, B. and Doddema-Winsemius, M. (2015), De Big 5 Persoonlijheidsfactoren: Een Methode voor het Beschrijven van Persoonlijkheidsfactoren [The Big 5 Personality Factors: A Method to Describe Personality Characteristics], Uitgeverij Nieuwezijds, Amsterdam.

DeHart-Davis, L. (2007), “The unbureaucratic personality”, Public Administration Review, Vol. 67 No. 5 , pp. 892-903.

DiMaggio, P.J. and Powell, W.W. (1983), "The iron cage revisited: institutional isomorphism and collective rationality", American Sociological Review, Vol. 48 No. 2, pp. 147-160.

Dunleavy, P., Margetts, Bastow, S. and Tinkler, J. (2006), "New public management is dead - long live digitalera governance", Journal of Public Administration Research and Theory, Vol. 16 No. 3, pp. 467-494.

Dunn, W.N. and Miller, D.Y. (2007), "A critique of the new public management and the neo-weberian state: advancing a critical theory of administrative reform", Public Organization Review, Vol. 7 No. 4, pp. s345-s358.

Frederickson, G.H. (1996), "Comparing the reinventing government movement with the new public administration", American Society for Public Administration, Vol. 56 No. 3, pp. 263-270.

Gaucher, D., Friesen, J. and Kay, A.C. (2011), "Evidence that gendered wording in job advertisements exists and sustains gender inequality", Journal of Personality and Social Psychology, Vol. 101 No. 1, pp. 109-128.

Godard, J. (2014), “The psychologization of employment relations?”, Human Resource Management Journal, Vol. 24 No. 1, pp. 1-18.

Goldberg, C.B. and Allen, D.G. (2008), "Black and white and read all over: race differences in reactions to recruitment web sites", Human Resource Management, Vol. 47 No. 2, pp. 217-236.

Goldberg, L.R. (1993), “The structure of phenotypic personality traits”, American Psychologist, Vol. 48 No. 1 , pp. 26-34.

Griffin, B. and Hesketh, B. (2004), "Why openness to experience is not a good predictor of job performance", International Journal of Selection and Assessment, Vol. 12 No. 3, pp. 243-251.

Hammerschid, G., Van de Walle, S., Andrews, R. and Bezes, P. (2016), Public Administration Reforms in Europe: The View From the Top, Edward Elgar Publishing, Cheltenham.

Hendriks, F. and Tops, P. (2003), "Local public management reforms in the Netherlands: fads, fashions and winds of change", Public Administration, Vol. 81 No. 2, pp. 301-323.

Hershatter, A. and Epstein, M. (2010), "Millennials and the world of work: an organization and management perspective", Journal of Business Psychology, Vol. 25 No. 2, pp. 211-223.

Hofstee, W.K.B., De Raad, B. and Goldberg, L.R. (1992), "Integration of the big five and circumplex approaches to trait structure", Journal of Personality and Social Psychology, Vol. 63 No. 1, pp. 146-163.

Holman, D., Martinez-Iñigo, D. and Totterdell, P. (2008), "Emotional labour and employee well-being: an integrative review", in Ashkanasy, N.M. and Cooper, C.L. (Eds), New Horizons in Management: Research Companion to Emotion in Organizations, Edward Elgar Publishing, Northampton, MA, pp. 301-315.

Hood, C. (1991), “A public management for all seasons?”, Public Administration, Vol. 69 No. 1, pp. 3-19. 
Hood, C. and Lodge, M. (2004), "Competency, bureaucracy, and public management reform: a comparative analysis”, Governance, Vol. 17 No. 3, pp. 313-333.

Kettl, D.F. (2002), The Transformation of Governance: Public Administration for Twenty-First Century America, Johns Hopkins University Press, Baltimore, MD and London.

Kickert, W.J.M. (1997), "Public governance in the Netherlands: an alternative to anglo-american 'managerialism'”, Public Administration, Vol. 75 No. 4, pp. 731-752.

Klijn, E.-H. (2008), “Governance and governance networks in Europe”, Public Management Review, Vol. 10 No. 4, pp. 505-525.

Klijn, E.-H. and Koppenjan, J.F.M. (2000), "Public management and policy networks: foundations of a network approach to governance”, Public Management, Vol. 2 No. 2, pp. 135-158.

Kruyen, P.M. and Van Genugten, M. (2020), "Opening up the black box of civil servants' competencies”, Public Management Review, Vol. 22 No. 1, pp. 118-140.

Lynn, L.E. (2008), "What is a neo-weberian state? Reflections on a concept and its implications", The NISPAcee Journal of Public Administration and Policy, Vol. 1 No. 2, pp. 17-30.

Merton, R.K. (1940), "Bureaucratic structure and personality”, Social Forces, Vol. 18 No. 4, pp. 560-568.

Microsoft Office Lens (2017), "Versions 2.0-2.3 [Computer software]. Microsoft”.

Moineddin, R., Matheson, F.I. and Glazier, R.H. (2007), “A simulation study of sample size for multilevel logistic regression models”, BMC Medical Research Methodology, Vol. 7 No. 34, available at: https://bmcmedresmethodol.biomedcentral.com/articles/10.1186/1471-2288-7-34\#citeas

Oberfield, Z. (2014), Becoming Bureaucrats. Socialization at the Front Lines of Government Service, University of Pennsylvania Press, Philadelphia, PA.

Olsen, J.P. (2005), "Maybe it is time to rediscover bureaucracy", Journal of Public Administration Research and Theory, Vol. 16 No. 1, pp. 1-24.

Osborne, D. and Gaebler, T. (1992), Reinventing Government: How the Entrepreneurial Spirit is Transforming the Public Sector, Addison-Wesley, Reading, MA.

Osborne, S.P. (2010), "Introduction: the (new) public governance: a suitable case for treatment?", in Osborne, S.P. (Ed.), The New Public Governance? Emerging Perspectives on the Theory and Practice of Public Governance, Routledge, London, pp. 1-16.

Pollitt, C. (2008), "An overview of the papers and propositions of the first trans-European dialogue (TED1)”, The NISPAcee Journal of Public Administration and Policy. Special Issue: A Distinctive Euraopean Model? The Neo-Weberian State, Vol. 1 No. 2, pp. 9-16.

Pollitt, C. and Bouckaert, G. (2004), Public Management Reform: A Comparative Analysis, 2nd ed., Oxford University Press, Oxford.

R Core Team (2017), R: A Language and Environment for Statistical Computing, R Foundation for Statistical Computing, Vienna, Austria.

Reissman, L. (1949), “A study of role conceptions in bureaucracy”, Social Forces, Vol. 27 No. 3, pp. 305-310.

Ryan, G., Gubern, M. and Rodriguez, I. (2000), "Recruitment advertising: the marketing-human resource interface”, International Advances in Economic Research, Vol. 6 No. 2, pp. 354-364.

Rynes, S.L., Bretz, R.D. Jr and Gerhart, B.A. (1991), "The importance of recruitment in job choice: a different way of looking”, Personnel Psychology, Vol. 44 No. 3, pp. 487-521.

Schaufeli, W.B. (2013), "What is engagement?", in Truss, C., Delbridge, R., Alfes, K., Shantz, A. and Soane, E. (Eds), Employee Engagement in Theory and Practice, Routledge, London, pp. 15-35.

Scott, W.R. (2003), Organizations: Rational, Natural, and Open Systems, Pearson Prentice Hall, Upper Saddle River, NJ.

Selznick, P. (1957), Leadership in Administration: A Sociological Interpretation, Harper \& Row, New York, NY.

Spence, M. (1973), “Job market signaling”, The Quarterly Journal of Economics, Vol. 87 No. 3, pp. $355-374$. 
IJPSM

33,1

Statistics Netherlands (2017a), “'Gemeenten op Alfabet 2017’ [Municipalities in alphabetic order]”, available at: www.cbs.nl/-/media/_excel/2016/38/gemeenten\%20alfabetisch\%202017.xls (September 1, 2017).

Statistics Netherlands (2017b), "Macroeconomics, national accounts, gross domestic product", available at: https://opendata.cbs.nl/statline/\#/CBS/en/dataset/82262ENG/table?ts=1519380 6569 (September 1, 2017).

Stevens, C.D. and Szmerekovsky, J.G. (2010), "Attraction to employment advertisements: advertisement wording and personality characteristics”, Journal of Managerial Issues, Vol. 22 No. 1, pp. 107-126.

Temple Lang, D. and the CRAN Team (2017), "XML: Tools for parsing and generating XML within R and S-Plus. R package version 3.98-1.7", available at: https://CRAN.R-project.org/package=XML

Thomas, J.C. (2013), "Citizen, customer, partner: rethinking the place of the public in public management", Public Administration Review, Vol. 73 No. 6, pp. 786-796.

Torfing, J. and Triantafillou, P. (2013), "What's in a name? Grasping new public governance as a political-administrative system", International Review of Public Administration, Vol. 18 No. 2, pp. 9-25.

Van Buuren, S. and Groothuis-Oudshoorn, K. (2011), "Mice: multivariate imputation by chained equations in R", Journal of Statistical Software, Vol. 45 No. 3, pp. 1-67.

Van de Walle, S., Hammerschmid, G., Andrews, R. and Bezes, P. (2016), "Introduction: Public administration reforms in Europe", in Hammerschid, G., Van de Walle, S., Andrews, R. and Bezes, P. (Eds), Public Administration Reforms in Europe: The View From the Top, Edward Elgar Publishing, Cheltenham, pp. 1-11.

Van der Loo, M.P.J. (2014), "The Stringdist package for approximate string matching”, The R Journal, Vol. 6 No. 1, pp. 111-122.

Vision (Computer software) (2017), "Google", available at: https://cloud.google.com/vision

Wilson, J.Q. (1989), Bureaucracy: What Government Agencies Do And Why They Do It, Basic Books, New York, NY.

Wright, B.E. (2015), "The science of public administration: problems, presumptions, progress, and possibilities", Public Administration Review, Vol. 75 No. 6, pp. 795-805.

Zalesny, M.D. and Farace, R.V. (1987), "Traditional versus open offices: a comparison of sociotechnical, social Relations, and symbolic meaning perspectives", Academy of Management Journal, Vol. 30 No. 2, pp. 240-259.

\section{Corresponding author}

Peter M. Kruyen can be contacted at: p.m.kruyen@fm.ru.nl

For instructions on how to order reprints of this article, please visit our website:

www.emeraldgrouppublishing.com/licensing/reprints.htm

Or contact us for further details: permissions@emeraldinsight.com 